\title{
THE WHITE FLOATING MARSH MARIGOLD, CALTHA NATANS, IN SASKATCHEWAN
}

VERNON L. HARMS, Fraser Herbarium, Department of Plant Ecology, University of Saskatchewan, Saskatoon

The white floating marsh-marigold, Caltha natans Pallas, differs from the common yellow marsh-marigold, C. palustris L., by having floating or creeping stems that are more slender and rooting at the nodes; kidneyshaped leaves that are smaller (mostly less than $3 \mathrm{~cm}$ wide), thin, and scarcely toothed; flowers smaller (about $1 \mathrm{~cm}$ broad), with the petal-like sepals white to pinkish, smaller (4-5 $\mathrm{mm}$ long); and numerous (about 30) simple pistils that mature into short-beaked follicular fruits less than $5 \mathrm{~mm}$ long clustered in a globose head (see Figure 1).

The white floating marsh-marigold, Caltha natans, has previously been regarded as very rare in Saskatchewan. Breitung recorded it only from Windrum Lake $\left(56^{\circ} 04^{\prime} \mathrm{N}, 104^{\circ} 10^{\prime} \mathrm{W}\right)$ (CAN) and Amisk Lake (on Meridian Creek !. H. Hudson 1437, DAO). ${ }^{2}$ Harms \& Hudson reported the species from 7 miles SSE of La Loche (Harms 17633, SASK). ${ }^{3}$ It was included by Argus \& White in their tentative list of rare and endangered plants of Saskatchewan. ${ }^{1}$

During the last five years, botanical field studies by the author and students in northern Saskatchewan have resulted in additional specimen records of this species from various localities. These amplify considerably the known distribution of the white floating marsh-marigold in the province. These new locality records, along with their collection data, are as follows: $8 \mathrm{mi}$. NE of Pelican Narrows $\left(55^{\circ} 15^{\prime} \mathrm{N}, 102^{\circ} 51^{\prime} \mathrm{W}\right)$, shallow stream pond near lake, Sep. 4, 1975, Harms $23364 B$ (SASK); ca. $1 \mathrm{mi}$. SE of Island
Falls Dam on Churchill River $\left(55^{\circ} 31 \frac{1}{2}\right.$ $\left.\mathrm{N}, 102^{\circ} 2012^{\prime} \mathrm{W}\right)$, shallow edge o beaver pond on small stream, Sep. 3 1975, Harms 23234 (SASK); SW side o Trade Lake on Churchill River (55 $2012^{\prime} \mathrm{N}, 103^{\circ} 48^{\prime} \mathrm{W}$ ), sedge fen a source of small creek, Aug. 6, 1974, J. \& I. Heilman 2629 (SASK); Reindee River, midway between Steephill Lake and The Two Rivers $\left(55^{\circ} 51^{\prime} \mathrm{N}, 103^{\circ} 05\right.$ $W)$, rare in shallow water marsh of protected bay, June 13, 1974, J. \& I Heilman 1467 (SASK); McDonald Creek, NE of Steephill Lake of Rein deer River $\left(56^{\circ} 02^{\prime} \mathrm{N}, 103^{\circ} 05^{\prime} \mathrm{W}\right)$, rare on creek banks, July 19; 1974, J. \& J. Heilman 2383A, 2398 (SASK); $4.5 \mathrm{mi}$. NE of Otter Rapids, Mile 58 of Hwy $102\left(55^{\circ} 43^{\prime} \mathrm{N}, 104^{\circ} 42^{\prime} \mathrm{W}\right)$, shallow water and mucky mud shore of stream channels in sedge/willow fen, Aug. 7, 1975, Harms 22760 (SASK); McLennon Lake, Mile 83 of Hwy. $102\left(55^{\circ} 55^{\prime} \mathrm{N}\right.$, $104^{\circ} 18^{\prime} \mathrm{W}$ ), in quiet pool of rocky stream, July 27, 1972, J. Ternier \& S. Lamont 1107 (SASK); ca. $1.5 \mathrm{mi}$. W of Southend, Numabin Bay of Reindeer Lake, Mile 133.6 of Hwy. $102\left(56^{\circ} 19^{\prime} \mathrm{N}\right.$, $\left.103^{\circ} 20^{\prime} \mathrm{W}\right)$, locally abundant in shallow ponds and wet mud flats, Aug. 5, 1975, Harms 22669 (SASK); 15 mi. W of Numabin Bay of Reindeer Lake, Mile 1.3 of Hwy. $105\left(56^{\circ} 16^{\prime} \mathrm{N}, 103^{\circ} 36^{\prime}\right.$ W), shallow gravelly stream in disturbed clearing, July 20, 1973, J. Ternier \& M. Jasieniuk 2191 (SASK); between Davin Lake and Atwater Lake, Mile 34 of Hwy. $105\left(56^{\circ} 48^{\prime} \mathrm{N}, 103^{\circ}\right.$ $361 / 2^{\prime} W$ ), abundant in small pond, July 16, 1975, Harms 21412 (SASK), Aug. 5, 1.75, Harms 22610 (SASK); ca. $3.5 \mathrm{mi} . \mathrm{S}$ of Courtenay Lake, Mile 98 of Hwy. 


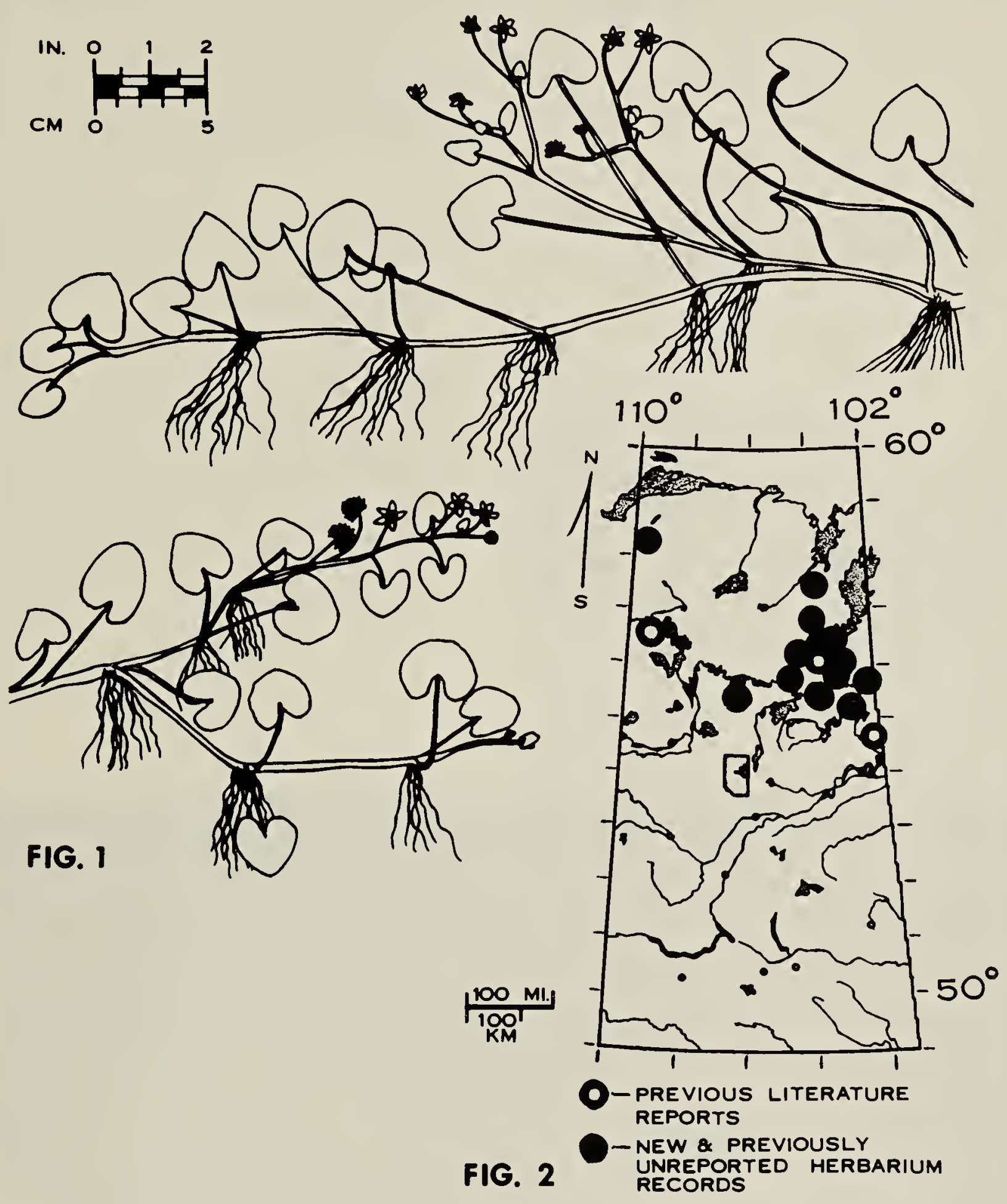

Figures 1 and 2 - The white floating marsh-marigold, Caltha natans: Fig. 1 Habit of plants. Fig. 2 - Distribution map of the known localities in Saskatchewan

$105\left(57^{\circ} 30^{\prime} \mathrm{N}, 103^{\circ} 58^{\prime} \mathrm{W}\right)$, abundant in mud and shallow water of sedge meadow at source of creek, June 22, 1973, J. Ternier \& M. Jasieniuk 1430 (SASK); Cluff Lake area, ca. $1 \mathrm{mi}$. W of Island Lake $\left(58^{\circ} 21^{\prime} \mathrm{N}, 109^{\circ} 42^{\prime} \mathrm{W}\right)$, locally numerous in shallow drainage channel in wet shore sedge fen, July 18 , 1977, Harms, Skoglund \& Wright 24485 (SASK); Besnard lake on $S$ shore $E$ of Narrows, June 20, 1977, D. Eagen 65
(SASK).

The previously reported and presently cited Saskatchewan locality records for the white floating marshmarigold are mapped in Figure 2 to better show the known distribution of this aquatic species in the province. In Saskatchewan, this species is thus far recorded only in the Northern Boreal Forest Region, with all locality records from either on or just south of the 
Canadian Precambrian Shield. It is not yet known from the Southern Boreal Forest Region (Mixedwood Section), except in its more northern extremities, nor from the Transitional Subarctic Lichen-Woodland Region in northeastern and northernmost Saskatchewan. Because of the relative frequency of recent collections of this species in northern Saskatchewan, as well as its local abundance at most known sites, this marsh-marigold can hardly be retained any longer in the status of a rare and possibly endangered species in the province. Instead this represents another example of how poorly known in the past has been the flora of northern Saskatchewan. Extensive floristic studies are still needed to upgrade ou present knowledge of the native flor especially for the north-central an northwestern regions of this provinc south of the immediate Lak Athabasca and Black Lake vicinities.

'ARGUS, G. \& D. WHITE. 1975. Preliminary List of the Rare Plants Saskatchewan. National Museum Canada.

${ }^{2}$ BREITUNG, A. J. 1957. Annotate catalogue of the vascular flora Saskatchewan. The American Midlan Naturalist, 58:1-72.

${ }^{3}$ HARMS V. L. \& J. H. HUDSON. 1974. Som new or noteworthy vascular plar records from northwestern Saska chewan. Rhodora, 76:39-44.

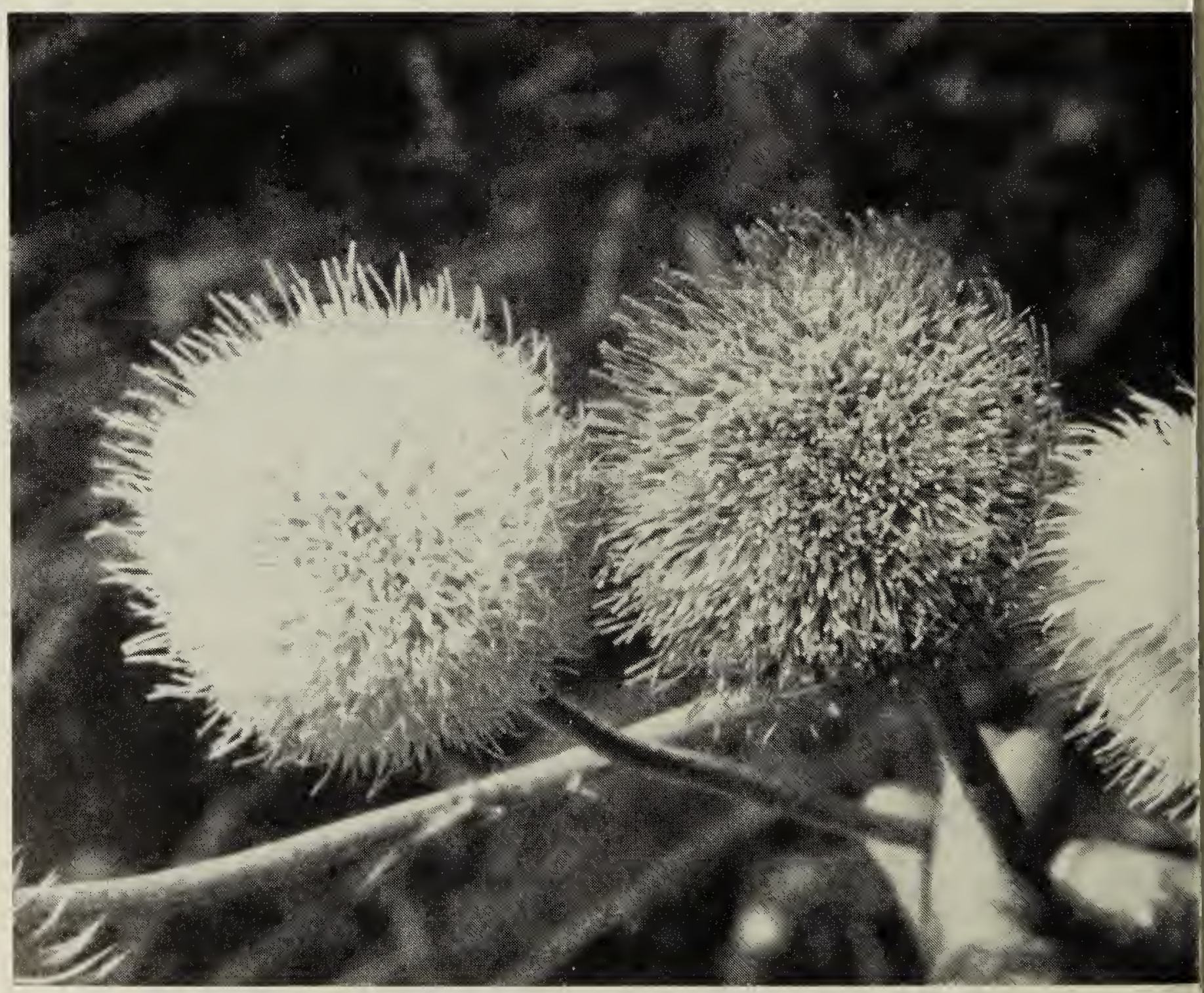

Contrasting White and Purple Heads of Nodding Thistle

I. B. Gollop 